\title{
Effects of carbon turnover time on terrestrial ecosystem carbon storage
}

\author{
Yaner Yan ${ }^{1,2}$, Xuhui Zhou ${ }^{2,3}$, Lifeng Jiang ${ }^{4}$, and Yiqi Luo ${ }^{4,5,6}$ \\ ${ }^{1}$ Key Laboratory for Eco-Agricultural Biotechnology around Hongze Lake/Collaborative Innovation Center of Regional \\ Modern Agriculture \& Environmental Protection, Huaiyin Normal University, Huai' an 223300, China \\ ${ }^{2}$ Tiantong National Station for Forest Ecosystem Research, Shanghai Key Lab for Urban Ecological Processes and \\ Eco-Restoration, School of Ecological and Environmental Sciences, East China Normal University, Shanghai 200062, China \\ ${ }^{3}$ Center for Global Change and Ecological forecasting, East China Normal University, Shanghai 200062, China \\ ${ }^{4}$ Center for Ecosystem Science and Society, Northern Arizona University, Arizona, 86011, USA \\ ${ }^{5}$ Department of Microbiology and Plant Biology, University of Oklahoma, OK, USA \\ ${ }^{6}$ Center for Earth System Science, Tsinghua University, Beijing, China
}

Correspondence to: Xuhui Zhou (xhzhou@des.ecnu.edu.cn)

Received: 11 May 2017 - Discussion started: 29 May 2017

Revised: 12 October 2017 - Accepted: 25 October 2017 - Published: 4 December 2017

\begin{abstract}
Carbon (C) turnover time is a key factor in determining $\mathrm{C}$ storage capacity in various plant and soil pools as well as terrestrial $\mathrm{C}$ sink in a changing climate. However, the effects of $\mathrm{C}$ turnover time on ecosystem $\mathrm{C}$ storage have not been well explored. In this study, we compared mean $\mathrm{C}$ turnover times (MTTs) of ecosystem and soil, examined their variability to climate, and then quantified the spatial variation in ecosystem $\mathrm{C}$ storage over time from changes in $\mathrm{C}$ turnover time and/or net primary production (NPP). Our results showed that mean ecosystem MTT based on gross primary production (GPP; $\mathrm{MTT}_{\text {EC_GPP }}=\mathrm{C}_{\text {pool }} / \mathrm{GPP}, 25.0 \pm 2.7$ years) was shorter than soil MTT $\left(\mathrm{MTT}_{\text {soil }}=\mathrm{C}_{\text {soil }} / \mathrm{NPP}, 35.5 \pm 1.2\right.$ years $)$ and NPP-based ecosystem MTT $\left(\mathrm{MTT}_{\mathrm{EC} \_\mathrm{NPP}}=\mathrm{C}_{\text {pool }} / \mathrm{NPP}\right.$, $50.8 \pm 3$ years; $\mathrm{C}_{\text {pool }}$ and $\mathrm{C}_{\text {soil }}$ referred to ecosystem or soil $\mathrm{C}$ storage, respectively). On the biome scale, temperature is the best predictor for $\operatorname{MTT}_{\mathrm{EC}}\left(R^{2}=0.77, p<0.001\right)$ and $\mathrm{MTT}_{\text {soil }}\left(R^{2}=0.68, p<0.001\right)$, while the inclusion of precipitation in the model did not improve the performance of $\operatorname{MTT}_{\text {EC }}\left(R^{2}=0.76, p<0.001\right)$. Ecosystem MTT decreased by approximately 4 years from 1901 to 2011 when only temperature was considered, resulting in a large $\mathrm{C}$ release from terrestrial ecosystems. The resultant terrestrial $\mathrm{C}$ release caused by the decrease in MTT only accounted for about $13.5 \%$ of that due to the change in NPP uptake $(159.3 \pm 1.45$ vs. $1215.4 \pm 11.0 \mathrm{Pg} \mathrm{C}$ ). However, the larger uncertainties in
\end{abstract}

the spatial variation of MTT than temporal changes could lead to a greater impact on ecosystem $\mathrm{C}$ storage, which deserves further study in the future.

\section{Introduction}

Rising atmospheric $\mathrm{CO}_{2}$ concentrations and the resultant climatic warming can substantially impact global carbon (C) budget (IPCC, 2007), leading to a positive or negative feedback to global climate change (Friedlingstein et al., 2006; Heimann and Reichstein, 2008). Projections of Earth system models (ESMs) show a substantial decrease in terrestrial C storage as the world warms (Friedlingstein et al., 2006), but the decreased magnitude is difficult to be quantified due to the complexity of terrestrial ecosystems in response to global change (Chambers and Li, 2007; Strassmann et al., 2008). For example, experimental and modeling studies have shown that elevated $\mathrm{CO}_{2}$ would enhance net primary production (NPP) and terrestrial C storage (Nemani et al., 2003; Norby et al., 2005), but warming could increase ecosystem $\mathrm{C}$ release, contributing to reduced $\mathrm{C}$ storage, especially in the colder regions (Atkin and Tjoelker, 2003; Karhu et al., 2014). Therefore, the response of terrestrial $\mathrm{C}$ storage to climate change depends on the responses of $\mathrm{C}$ flux and turnover time in various $\mathrm{C}$ pools (i.e., plant, litter and soil; Parton et al., 
1987; Potter et al., 1993; Luo et al., 2003; Xia et al., 2013). When simulated soil C from CMIP5 Earth system models have been evaluated, global soil $\mathrm{C}$ changed 5.9-fold across models in response to a 2.6-fold variation in NPP and a 3.6fold variation in global soil $\mathrm{C}$ turnover times (Todd-Brown et al., 2013).

In a given environmental condition, ecosystem $\mathrm{C}$ storage capacity refers to the amount of $\mathrm{C}$ that a terrestrial ecosystem can store at the steady state, determined by $\mathrm{C}$ influx and turnover time (Xia et al., 2013). External environmental factors, such as climate change and land use change, would dynamically influence both ecosystem $\mathrm{C}$ influx and turnover time and then change terrestrial $C$ storage capacity. Thus, the changed magnitude of ecosystem $\mathrm{C}$ storage can be expressed by changes in both NPP and mean C turnover time (Luo et al., 2003). The spatial variation of NPP changes over time and the effects of climate change have been relatively well quantified by manipulative experiments (Rustad et al., 2001; Luo et al., 2006), satellite data (Zhao and Running, 2010) and data assimilation (Luo et al., 2003; Zhou and Luo, 2008; Zhou et al., 2012). It has been shown that differences in NPP contributed significantly to differences in soil $\mathrm{C}$ across models using a reduced complexity model with NPP and temperature (Todd-Brown et al., 2013). In contrast, the spatial variation of $\mathrm{C}$ turnover time in terrestrial ecosystems and its contribution to $\mathrm{C}$ storage have not been well quantified, especially on the regional or global scale.

Ecosystem $\mathrm{C}$ turnover time is the average time that a $\mathrm{C}$ atom resides in an ecosystem from entrance to the exit (Barrett, 2002). Several methods have been used to estimate the $\mathrm{C}$ turnover time, such as $\mathrm{C}$ balance method by estimating ratios of C pools and fluxes (Vogt et al., 1995), C isotope tracing (Ciais et al., 1999; Randerson et al., 1999) and measurements of radiocarbon accumulation in the undisturbed soils (Trumbore et al., 1996). However, most methods mainly focused on various $\mathrm{C}$ pools (i.e., leaf, root, soil) and on a small scale (i.e., $\mathrm{C}$ isotope tracing, radiocarbon dating). Spatial pattern of ecosystem $\mathrm{C}$ turnover time is relatively difficult to estimate (Zhou and Luo, 2008), which needs to incorporate individual plant and soil $\mathrm{C}$ pools and their $\mathrm{C}$ turnover time into ecosystem models. The inverse modeling has been used to estimate ecosystem mean C turnover time in the USA and Australia with high spatially heterogeneous distribution (Barrett, 2002; Zhou and Luo, 2008; Zhou et al., 2012). The ratio of $\mathrm{C}$ storage to flux is another common method to estimate ecosystem turnover time on a regional or global scale (Gill and Jackson, 2000; Chen et al., 2013). For example, Carvalhais et al. (2014) estimated ecosystem C turnover time as the ratio of $\mathrm{C}$ storage (soil and vegetation $\mathrm{C}$ ) and gross primary production (GPP) and examined their correlations to climate. However, it mainly focused on the comparison of global $\mathrm{C}$ turnover time calculated by modeled results from CIMP5 with those from observed data. In our study, we extended litter $\mathrm{C}$ and vegetation $\mathrm{C}$ from different data sets into ecosystem $\mathrm{C}$ storage to estimate $\mathrm{C}$ turnover time and eval- uated their uncertainty. We also examined the changes in ecosystem $\mathrm{C}$ storage over time from changes in $\mathrm{C}$ turnover time and/or NPP.

In past decades, two types of mean $\mathrm{C}$ turnover times have been suggested for terrestrial ecosystems: the GPP-based or the NPP-based mean turnover time according to the terrestrial C models with GPP or NPP as their C inputs, respectively (Thompson and Randerson, 1999; NPP is GPP minus plant respiration). In addition, soil $\mathrm{C}$ turnover time is usually estimated using field sampling as the global turnover time for model validation. However, the differences in $\mathrm{C}$ turnover times among versions $\mathrm{C}$ pools remain unclear. Therefore, we calculated the GPP- and NPP-based ecosystem and soil turnover times through a similar method to explore the difference and its variability to climate. Thus, our objectives were (1) to estimate the difference between GPP- and NPPbased ecosystem and soil mean $\mathrm{C}$ turnover time, (2) to explore their relationships with climatic factors and (3) to quantify ecosystem $\mathrm{C}$ storage over time from changes in ecosystem C turnover time from 1901 to 2011.

\section{Materials and methods}

\subsection{Data collection}

Three data sets were used to calculate ecosystem and soil mean $\mathrm{C}$ turnover times, examine their variability to climate and investigate effects of $\mathrm{C}$ turnover time on ecosystem $\mathrm{C}$ storage, including $\mathrm{C}$ influx (GPP and NPP), $\mathrm{C}$ storage in different $\mathrm{C}$ pools (soil, plant and litter) and climate variables (temperature, precipitation and potential evapotranspiration). GPP and NPP were extracted from MODIS products (MOD17) on an 8-day interval with a nominal $1 \mathrm{~km}$ resolution from 24 February 2000. The multi-annual average GPP and NPP values from 2000 to 2009 with the spatial resolution of $0.083^{\circ} \times 0.083^{\circ}$ were used in this study (Zhao and Running, 2010).

The Harmonized World Soil Database (HWSD; Hiederer and Köchy, 2012) provided empirical estimates of global soil C storage, a product of the Food and Agriculture Organization of the United Nations and the Land Use Change and Agriculture Program of the International Institute for Applied System Analysis (FAO/IIASA/ISRIC/ISSCAS/JRC, 2012). Global soil organic $C(S O C)$ at the topsoil $(0-30 \mathrm{~cm})$ and subsoil layers $(30-100 \mathrm{~cm})$ has been estimated using the amended HWSD with estimates derived from other global data sets for these layers (Hiederer and Köchy, 2012). We used the amended HWSD SOC to calculate $\mathrm{C}$ turnover time (http://eusoils.jrc.ec.europa.eu). However, HWSD only provides an estimate of soil $\mathrm{C}$ storage at the top $1 \mathrm{~m}$ of soil and has largely underestimated total soil C. It has been indicated that global SOC storage in the top $3 \mathrm{~m}$ of soil was $56 \%$ more than that for the first meter, which could change estimates of the turnover time (Jobbagy and Jackson, 2000). We discussed 
this caveat in the discussion section of this study. It is well known that HWSD has underestimated soil $\mathrm{C}$ at high latitudes (Carvalhais et al., 2014). We thus estimated turnover time at high latitudes with the Northern Circumpolar Soil Carbon Database (NCSCD), which is an independent survey of soil C in this region (Tarnocai et al., 2009). For biomass, Gibbs (2006) estimated the spatial distribution of the above and belowground $\mathrm{C}$ stored in living plant material by updating the classic studies of Olson et al. $(1983,1985)$ with a contemporary map of global vegetation distribution (Global Land Cover database; Bartholomé and Belward, 2005). Each cell in the gridded data set was coded with an estimate of mean and maximum $\mathrm{C}$ density values based on its land cover class, so this data set mainly represents plant biomass $\mathrm{C}$ at a biome level (Gibbs, 2006).

The litter data set was extracted from 650 published and unpublished documents (Holland et al., 2014). Each record represents a site, including site description, method, litterfall, litter mass and nutrients. We calculated the mean and median of litter mass for each biome, and then assigned the value for each grid according to the biome types, forming the global pattern of litter $\mathrm{C}$ storage using the method of Matthews (1997) in ARCGIS software (ESRI Inc., Redlands, CA).

Global climate databases produced by the Climate Research Unit (CRU) at the University of East Anglia were used to analyze the climatic effect on ecosystem mean $\mathrm{C}$ turnover time. We used mean $0.5^{\circ} \times 0.5^{\circ}$ gridded air temperature, precipitation and potential evapotranspiration in CRU_TS 3.20 (Harris et al., 2014), specifically their means from 2000 to 2009.

We aggregated all data sets into a biome level for data match, so the biome map was extracted from the GLC 2000 (Bartholomé and Belward, 2005) and regulated by MODIS. We assigned 22 land cover classes among three temperature zones (i.e., tropical, temperate and boreal) by taking the most common land cover from the original underlying $0.083^{\circ} \times 0.083^{\circ}$ data. Eight typical biomes were zoned with ARCGIS 10 corresponding to plant function types (PFTs) in CABLE model as described in Xia et al. (2013): evergreen needleleaf forest (ENF), evergreen broadleaf forest (EBF), deciduous needleleaf forest (DNF), deciduous broadleaf forest (DBF), tundra, shrubland, grassland and cropland. All of the data were re-gridded by ARCGIS 10 to a common projection (WGS 84) and $1^{\circ} \times 1^{\circ}$ spatial resolution. The regridding approach for $\mathrm{C}$ fluxes and pools (i.e., GPP, NPP, soil $\mathrm{C}$ and litter $\mathrm{C}$ ) assumed conservation of mass that a latitudinal degree was proportional to distance for the close grid cells (Todd-Brown et al., 2013). A nearest-neighbor approach was used for land cover classes and a bilinear interpolation was used for climate variables (i.e., temperature, precipitation).

\subsection{Estimation of ecosystem mean $\mathrm{C}$ turnover time}

Terrestrial ecosystem includes many $\mathrm{C}$ pools with largely varying turnover times from days to millennia, but it is difficult to collect the observed data sets of $\mathrm{C}$ pools and flux for each component (e.g., leaf, wood and different soil $\mathrm{C}$ fractions) on the global scale. It thus is impossible to estimate individual pools' turnover time. In this study, we estimated the whole-ecosystem $\mathrm{C}$ turnover time as the ratio of $\mathrm{C}$ pools to flux based on the observed data sets. There were clearly some limitations when the ecosystem was considered as a single pool, which is further discussed in the discussion section. For terrestrial ecosystems, the $\mathrm{C}$ pools $\left(\mathrm{C}_{\text {pool }}\right)$ is composed of three parts: plant, litter and soil, and $\mathrm{C}$ outfluxes include all C losses (autotrophic, $R_{\mathrm{a}}$, and heterotrophic respiration, $R_{\mathrm{h}}$ ) as well as by fires and harvest. At the steady state, $\mathrm{C}$ outflux equals to $\mathrm{C}$ influx, which is the $\mathrm{C}$ uptake through GPP, so ecosystem C mean turnover time $\left(\mathrm{MTT}_{\mathrm{EC}}\right)$ can be equivalently calculated as the ratio between $\mathrm{C}$ storage in vegetation, soils and litters, and the influx into the pools, GPP:

$\mathrm{MTT}_{\mathrm{EC}}=\frac{\mathrm{C}_{\mathrm{pool}}}{\mathrm{GPP}}$

However, the steady state in nature is rare, so we relax the strict steady-state assumption and computed the ratio of $\mathrm{C}_{\text {pool }}$ to GPP as apparent whole-ecosystem turnover time and interpret the quantity as an emergent diagnostic at the ecosystem level (Carvalhais et al., 2014). We used multi-year GPP to calculate MTT in order to reduce the effect of the non-steady state, since it was difficult to evaluate how this assumption would affect model results. To make for better comparison, we also estimated the NPP-based ecosystem MTT $\left(\mathrm{MTT}_{\mathrm{EC} \_\mathrm{NPP}}=\mathrm{C}_{\text {pool }} / \mathrm{NPP}\right)$. A similar method was used to calculate soil MTT $\left(\mathrm{MTT}_{\text {soil }}=\mathrm{C}_{\text {soil }} / \mathrm{NPP}\right)$.

\subsection{The climate effects on ecosystem mean $\mathrm{C}$ turnover time}

To explore the combining effects of precipitation and temperature on ecosystem and soil $\mathrm{C}$ turnover time, aridity index (AI) was calculated as follows:

$\mathrm{AI}=\frac{\mathrm{MAP}}{\mathrm{PET}}$,

where PET is the potential evapotranspiration and MAP is mean annual precipitation (Middleton and Thomas, 1997). AI is a bioclimatic index including both physical phenomena (precipitation and potential evapotranspiration) and biological processes (plant transpiration) related to edaphic factors.

The relationships were examined between MTT and mean annual temperature (MAT, $\left.{ }^{\circ} \mathrm{C}\right)$, MAP (mm) and AI at the biome level. The regression analyses $\left(\mathrm{MTT}=a e^{-\mathrm{bMATorMAP}}\right)$ were performed in STATISTICA 10 (StatSoft Inc., 2011), where $a$ and $b$ are the coefficients. The coefficient of determination $\left(R^{2}\right)$ was used to 
measure the phase correlation between MTT and climate factors. Here, we also calculated a $Q_{10}$ value (i.e., $Q_{10}$, a relative increase in mean turnover time for a $10^{\circ} \mathrm{C}$ increase in temperature, $Q_{10}=e^{10 b}, b$, the coefficients of $\mathrm{MTT}=a e^{-\mathrm{bMATorMAP}}$ ), which is used in most models to simulate $\mathrm{C}$ decomposition.

\subsection{The effects of turnover time on ecosystem C storage}

Ecosystem C storage capacity at the steady state is represented by NPP $\times$ MTT (Lou et al., 2003), so the difference of ecosystem C storage from 1901 to 2011 could be calculated as follows:

$$
\begin{aligned}
& \Delta \mathrm{C}_{\mathrm{pool}}=\mathrm{NPP}_{2011} \times \mathrm{MTT}_{2011}-\mathrm{NPP}_{1901} \times \mathrm{MTT}_{1901}, \\
& \Rightarrow \Delta \mathrm{C}_{\mathrm{pool}}=\mathrm{NPP}_{2011} \times \mathrm{MTT}_{2011}-\left(\mathrm{NPP}_{2011}-\Delta \mathrm{NPP}\right) \\
& \quad \times\left(\mathrm{MTT}_{2011}-\Delta \mathrm{MRT}\right) \\
& \Rightarrow \Delta \mathrm{C}_{\mathrm{pool}}=\mathrm{NPP}_{2011} \times \Delta \mathrm{MTT}+\mathrm{MTT}_{2011} \\
& \quad \times \Delta \mathrm{NPP}-\Delta \mathrm{NPP} \times \Delta \mathrm{MTT}
\end{aligned}
$$

where $\mathrm{NPP}_{1901(2011)}$ and $\mathrm{MTT}_{1901(2011)}$ refer to NPP and MTT at time 1901 or $2011 . \Delta \mathrm{C}_{\text {pool }}(\Delta \mathrm{NPP}$ or $\Delta \mathrm{MTT})$ is the difference between ecosystem $\mathrm{C}$ storage (NPP or MTT) at time 2011 and 1901. The first component $\left(\mathrm{NPP}_{2011} \times \Delta \mathrm{MTT}\right)$ represents the effects of changes in MTT on ecosystem $\mathrm{C}$ storage. The second component $\left(\triangle \mathrm{NPP} \times \mathrm{MTT}_{2011}\right)$ is the effects of changes in NPP on ecosystem $\mathrm{C}$ storage, and $\Delta \mathrm{NPP} \times \Delta \mathrm{MTT}$ is the interactive effects of both changes in NPP and MTT.

To assess ecosystem C storage from the changes in MTT or NPP, ecosystem MTT in 1901 and 2011 was calculated using an exponential equation between ecosystem MTT and temperature $\left(\mathrm{MTT}=a e^{-\mathrm{bMAT}}\right)$. Here, we assumed that the spatial correlation between temperature and MTT was identical to the temporal correlation between these variables. NPP in 2011 was derived from products (MOD17) and NPP in 1901 was averaged from the eight models' simulated results (CanESM2, CCSM4, IPSL-CM5A-LR, IPSL-CM5BLR, MIROC-ESM, MIROC-ESM-CHEM, NorESM1-M and NorESM1-ME). Our previous study found that the modeled NPP was near MODIS-estimated NPP and their difference was mostly less than $0.05 \mathrm{~kg} \mathrm{C} \mathrm{m}^{-2} \mathrm{yr}^{-1}$ (Yan et al., 2014).

\subsection{Uncertainty analysis and sensitivity analysis}

A limitation of the above data sets is that the uncertainties are poorly quantified. The global mean of C fluxes (GPP and NPP) and pools (soil, litter and plant) were calculated by 1000 simulations, respectively, through Markov chain Monte Carlo (MCMC) sampling from a gamma distribution (CRAN: MCMCpack; Martin, et al., 2011). For each variable, the confidence interval (CI) was estimated as the 2.5 and 97.5 percentile of mean values of the 1000 simulations.
It was also applied to estimate the confidence interval of ecosystem $\mathrm{C}$ storage and ecosystem mean $\mathrm{C}$ turnover time.

\section{Results}

\subsection{Ecosystem C storage}

On average, terrestrial $\mathrm{C}$ storage (plant biomass + soil + litter) was $22.0 \mathrm{~kg} \mathrm{Cm}^{-2}$ (with a $95 \% \mathrm{CI}$ of $21.85-$ $22.50 \mathrm{~kg} \mathrm{C} \mathrm{m}^{-2}$ ) on the global scale, which largely varied with vegetation and soil type (Fig. 1). Among the forest biomes, ecosystem $\mathrm{C}$ storage was the highest in boreal evergreen needleleaf forest (ENF) and the lowest in deciduous broadleaf forest (DBF). Soil $\mathrm{C}$ was the largest $\mathrm{C}$ pool in terrestrial ecosystems, accounting for more than $60 \%$ of ecosystem $\mathrm{C}$ storage, while $\mathrm{C}$ storage from litter and plant biomass only represented less than 10 and $30 \%$, respectively (Fig. 1b). Among eight typical biomes associated with plant functional types (PFTs, Table 1), the order of ecosystem $C$ storage contribution followed as $\operatorname{ENF}\left(34.84 \pm 0.02 \mathrm{~kg} \mathrm{C} \mathrm{m}^{-2}\right)>\operatorname{DNF}(25.30 \pm 0.03$ $\left.\mathrm{kg} \mathrm{Cm}^{-2}\right)>\mathrm{EBF}\left(22.70 \pm 0.01 \mathrm{~kg} \mathrm{C} \mathrm{m}^{-2}\right)>$ shrubland $\left(18.29 \pm 0.02 \mathrm{~kg} \mathrm{Cm}^{-2}\right)>\mathrm{DBF}\left(16.51 \pm 0.02 \mathrm{~kg} \mathrm{Cm}^{-2}\right)$ $>$ tundra $\left(14.16 \pm 0.02 \mathrm{~kg} \mathrm{C} \mathrm{m}^{-2}\right) /$ cropland $(14.58 \pm 0.01$ $\left.\mathrm{kg} \mathrm{C} \mathrm{m}{ }^{-2}\right)>$ grassland $\left(10.80 \pm 0.01 \mathrm{~kg} \mathrm{C} \mathrm{m}^{-2}\right)$.

\subsection{Mean $\mathrm{C}$ turnover time}

Ecosystem mean $\mathrm{C}$ turnover time (MTT) was 25.0 years (with a $95 \% \mathrm{CI}$ of 23.3-27.7 years) based on GPP data and 50.8 years (with a $95 \%$ CI of $47.8-53.8$ years) on NPP data (Table 1), while soil MTT was shorter than NPP-based MTT with the value of 35.5 years (with a $95 \%$ CI of 34.936.7 years). MTT varied among biomes due to the different climate forcing (Table 1 and Fig. 2). The longest MTT occurred at high latitudes while the shortest one was in tropical zone. Among the forest biomes, DNF had the longest MTT with the lowest mean temperature $\left(-7.9^{\circ} \mathrm{C}\right)$, while the shortest MTT was in EBF with the highest temperature $\left(24.5^{\circ} \mathrm{C}\right)$ and precipitation $(2143 \mathrm{~mm})$. Although ecosystem $\mathrm{C}$ storage was low in tundra $\left(14.16 \mathrm{~kg} \mathrm{C} \mathrm{m}^{-2}\right)$, it had the longest MTT. Therefore, the order of GPP-based ecosystem MTT among biomes differed for ecosystem $\mathrm{C}$ storage, with tundra ( $99.704 \pm 6.14$ years) $>\mathrm{DNF}(45.27 \pm 2.43$ years $)$ or ENF $(42.23 \pm 2.01$ years $)>$ shrubland $(27.77 \pm 2.25$ years $)$ $>$ grassland $(26.00 \pm 1.41$ years $)>$ cropland $(14.91 \pm 0.40$ years) or DBF $(13.29 \pm 0.68$ years $)>\operatorname{EBF}(9.67 \pm 0.21$ years). Soil MTT had a similar order to ecosystem MTT with different values (Table 1). At high latitudes, ecosystem MTT could increase up to 145 years if soil C storage was calculated from NCSCD data set (500 vs. 290 Pg C from HWSD, Fig. 3) due to higher soil $\mathrm{C}$ storage, while the global average of soil MTT could increase up to 40.8 years when NCSCD data set was considered. 
Table 1. The density of ecosystem $\mathrm{C}$ storage $\left(\mathrm{kg} \mathrm{C} \mathrm{m}^{-2}\right)$, mean turnover time (MTT, years), mean annual temperature (MAT) and precipitation (MAP) for the eight biomes. Ecosystem MTT was calculated based on GPP and NPP.

\begin{tabular}{|c|c|c|c|c|c|c|}
\hline \multirow[b]{2}{*}{ Biome } & \multirow[b]{2}{*}{$\begin{array}{r}\text { Ecosystem C } \\
\text { storage }\left(\mathrm{kg} \mathrm{C} \mathrm{m}^{-2}\right)\end{array}$} & \multicolumn{2}{|c|}{ Ecosystem MTT (years) } & \multirow[b]{2}{*}{$\begin{array}{r}\text { Soil MTT } \\
\text { (years) }\end{array}$} & \multirow[b]{2}{*}{$\begin{array}{r}\text { MAT } \\
\left({ }^{\circ} \mathrm{C}\right)\end{array}$} & \multirow[b]{2}{*}{$\begin{array}{l}\text { MAP } \\
(\mathrm{mm})\end{array}$} \\
\hline & & $\mathrm{MTT}_{\mathrm{GPP}}$ & $\mathrm{MTT}_{\mathrm{NPP}}$ & & & \\
\hline ENF & $34.8 \pm 0.02$ & $42.23 \pm 2.01$ & $58.54 \pm 2.16$ & $39.62 \pm 1.22$ & 3.5 & 760.5 \\
\hline EBF & $22.7 \pm 0.01$ & $9.67 \pm 0.21$ & $18.43 \pm 0.43$ & $8.96 \pm 0.21$ & 24.5 & 2143.5 \\
\hline DNF & $25.3 \pm 0.03$ & $45.27 \pm 2.43$ & $75.80 \pm 2.71$ & $53.50 \pm 1.71$ & -7.9 & 401.4 \\
\hline DBF & $16.5 \pm 0.02$ & $13.29 \pm 0.68$ & $22.02 \pm 1.00$ & $12.08 \pm 0.69$ & 16.1 & 988.4 \\
\hline Tundra & $14.2 \pm 0.02$ & $99.74 \pm 6.14$ & $132.86 \pm 4.40$ & $122.88 \pm 5.54$ & -11.1 & 291.1 \\
\hline Shrubland & $18.3 \pm 0.02$ & $27.77 \pm 2.25$ & $43.41 \pm 2.37$ & $36.22 \pm 2.01$ & 9.3 & 643.6 \\
\hline Grassland & $10.8 \pm 0.01$ & $26.00 \pm 1.41$ & $39.51 \pm 2.11$ & $34.37 \pm 2.20$ & 9.4 & 605.5 \\
\hline Cropland & $14.6 \pm 0.01$ & $14.91 \pm 0.40$ & $23.06 \pm 0.84$ & $17.72 \pm 0.58$ & 15.4 & 885.7 \\
\hline
\end{tabular}

* ENF: evergreen needleleaf forest; EBF: evergreen broadleaf forest; DNF: deciduous needleleaf forest; DBF: deciduous broadleaf forest.

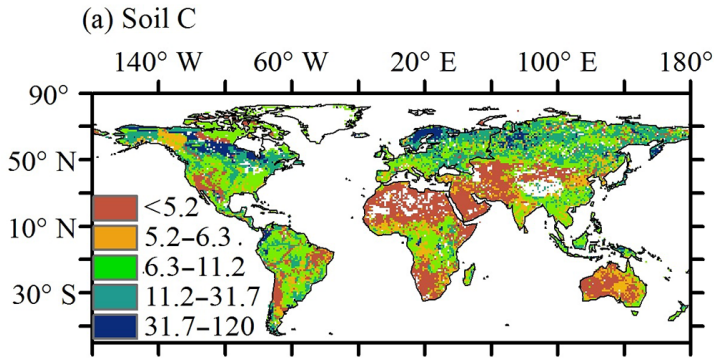

(c) Litter C

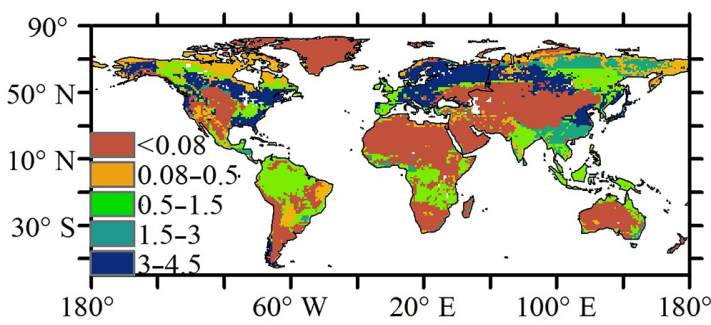

(b) Biome C

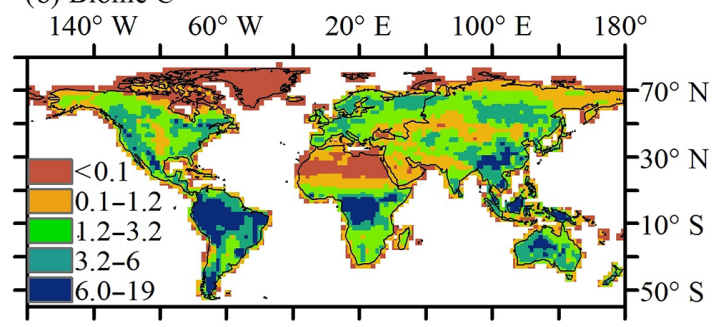

(d) Ecosystem C

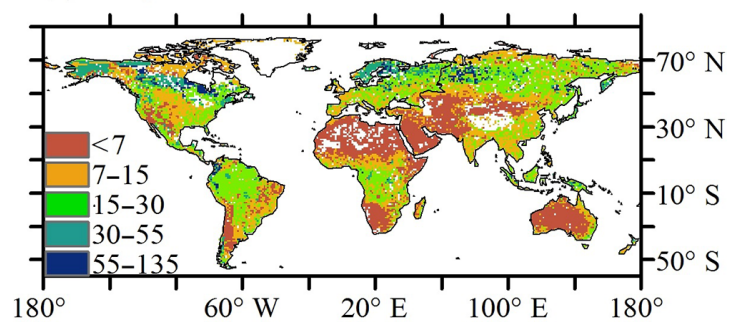

Figure 1. Spatial pattern of soil C (a), biome C (b), litter C (c) and ecosystem C storage (d) on the grid scale $\left(1^{\circ} \times 1^{\circ}\right) . \mathrm{Unit}^{\mathrm{kg}} \mathrm{kg} \mathrm{m}^{-2}$. Ecosystem $\mathrm{C}$ storage was calculated from plant biomass, soil and litter $\mathrm{C}$ pools.

\subsection{Effects of climate on ecosystem mean turnover time (MTT)}

Ecosystem MTT significantly decreased with mean annual temperature (MAT) and mean annual precipitation (MAP) as described by an exponential equation: $\mathrm{MTT}=57.06 e^{-0.07 \mathrm{MAT}}\left(R^{2}=0.77, P<0.001\right)$ and $\mathrm{MTT}=$ $103.07 e^{-0.001 \mathrm{MAP}}\left(R^{2}=0.34, P<0.001\right.$, Fig. 4$)$. There was no correlation between ecosystem MTT and aridity index (AI, Fig. 4c). Similar relationships occurred between soil MTT and MAT/MAP $\left(\mathrm{MTT}_{\text {soil }}=58.40 e^{-0.08 \mathrm{MAT}}\right.$, $R^{2}=0.68, \quad P<0.001 ; \quad$ and $\mathrm{MTT}_{\text {soil }}=109.98 e^{-0.002 \mathrm{MAP}}$, $R^{2}=0.48, P<0.001$; Fig. 5). There was different temperature sensitivity of mean turnover time $\left(Q_{10}\right)$ for ecosystem MTT $\left(Q_{10}=1.95\right)$ and soil MTT $\left(Q_{10}=2.23\right)$ on the biome scale. When MAP was incorporated into a multivariate regression function of ecosystem MTT with MAT, the relationships could not be significantly improved. MAP improved the explanation of variance of soil MTT $\left(R^{2}\right.$ from 0.68 to 0.76 ), although there was significant covariance of MAP and MAT $\left(R^{2}=0.60\right)$. However, the relationship between MTT and AI was not clear due to the scale limit. When we separated ecosystem MTT into two categories according to aridity index (i.e., $\mathrm{AI}>1$ and $\mathrm{AI}<1$ ), the relationships between ecosystem MTT and MAT did not significantly change (Fig. 4e, h) compared with that with all data (Fig. 4b). The relationship of ecosystem MTT with MAP significantly increased when $\mathrm{AI}>1$, but decreased when $\mathrm{AI}<1$. However, the same regression function of soil MTT with MAT largely improved the explanation of the variance 
(a) GPP-based MTT
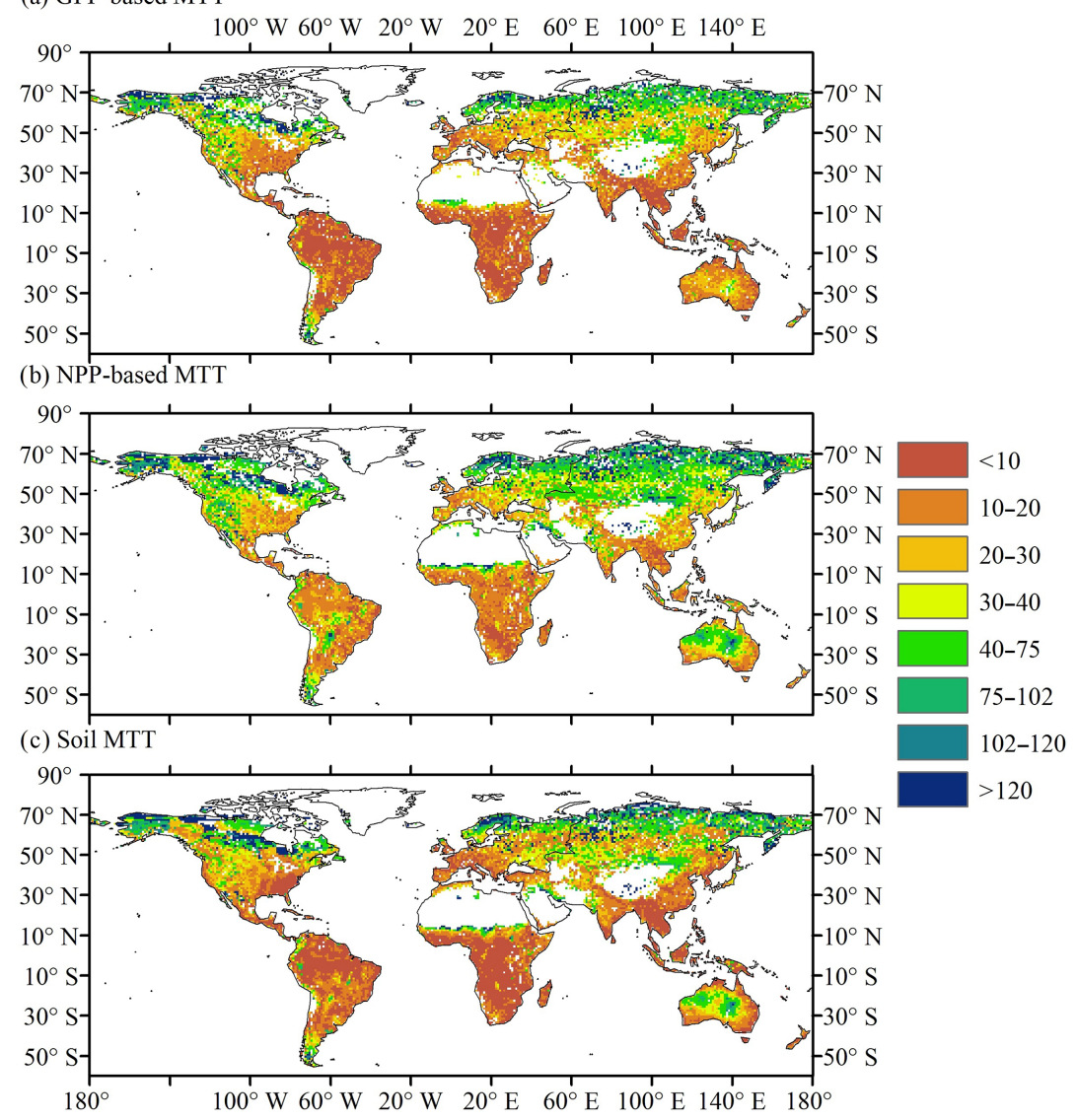

Figure 2. Spatial pattern of mean turnover time (MTT, years) based on biome types and GPP (a), NPP (b) and soil C (c) using the C balance methods.

when $\mathrm{AI}>1$ (Fig. 5e; MTT $=58.67 e^{-0.08 \mathrm{MAT}}, R^{2}=0.76$, $P<0.001)$. The relationships between soil MTT and MAP were both improved when $\mathrm{AI}>1$ and $\mathrm{AI}<1$ (Fig. 5e, h).

\subsection{Temporal variations of ecosystem mean turnover time and $C$ storage}

The average increase in global air temperature was around $1^{\circ} \mathrm{C}$ from 1901 to 2011 based on the Climate Research Unit (CRU) data sets, ranging from -2.5 to $5.9^{\circ} \mathrm{C}$ (Fig. 6c). When the regression function between ecosystem MTT and MAT was used to estimate ecosystem MTT in 1901 and 2011 (Fig. 4), the ecosystem MTT decreased by approximately 4 years on average (Fig. 6a). The largest change in ecosystem MTT occurred in the cold zones. In tundra, ecosystem MTT decreased by more than 10 years due to the larger increase in temperature $\left(\sim 2^{\circ} \mathrm{C}\right)$ than other regions. The average NPP increased by approximately $0.3 \pm 0.003 \mathrm{Kg} \mathrm{C} \mathrm{m}^{-2} \mathrm{yr}^{-1}$ over 110 years with the greatest range of $0-0.6 \mathrm{Kg} \mathrm{C} \mathrm{m}^{-2} \mathrm{yr}^{-1}$ (Fig. 6b).

The changes in ecosystem MTT and NPP across 110 years caused decrease or increase in terrestrial $\mathrm{C}$ storage. Ecosystem C storage decreased by $159.3 \pm 1.45 \mathrm{Pg} \mathrm{C}$ from 1901 to $2011(\Delta$ MTT $\times$ NPP) from the decrease in MTT, with the largest decrease in tundra and boreal forest (more than $12 \mathrm{~g} \mathrm{C} \mathrm{m}^{-2}$ ) and little decrease in tropical zones (Fig. 7a and e). The interactive changes of both NPP and MTT caused a decrease of $129.4 \pm 1.31 \operatorname{Pg} \mathrm{C}(\Delta \mathrm{MTT} \times \Delta \mathrm{NPP})$ with a similar spatial pattern (Fig. 7c). However, the increase in NPP directly raised ecosystem C storage up to $1215.4 \pm 11.0 \mathrm{PgC}$ from 1901 to 2011 , with a range of $30-150 \mathrm{~g} \mathrm{C} \mathrm{m}^{-2}$ in most areas (MTT $\times \Delta$ NPP, Fig. 7b). The MTT-induced changes in ecosystem $\mathrm{C}$ storage only accounted for about $13.5 \%$ of that driven by NPP due to the different weights $(\Delta$ MTT $\times$ NPP vs. MTT $\times \Delta$ NPP $)$. The spatial pattern of the NPP-driven changes mostly represented the spatial pattern of the changes in ecosystem $\mathrm{C}$ storage (Fig. 7e).

\section{Discussion}

\subsection{Global pattern of mean turnover time}

In this study, we used the ratio of $\mathrm{C}$ storage to $\mathrm{C}$ flux to calculate the GPP-based, NPP-based and soil MTT and compared 
(a) MTT based on HWSD soil C

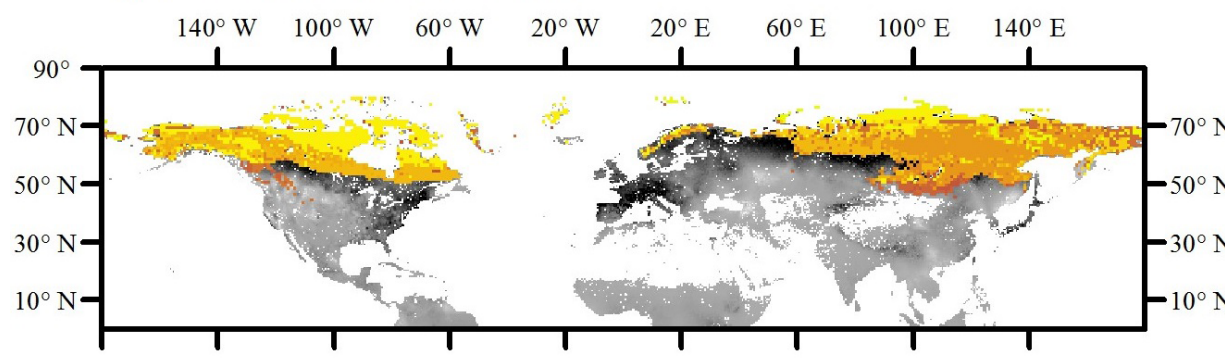

(b) MTT based on NCSCD soil C

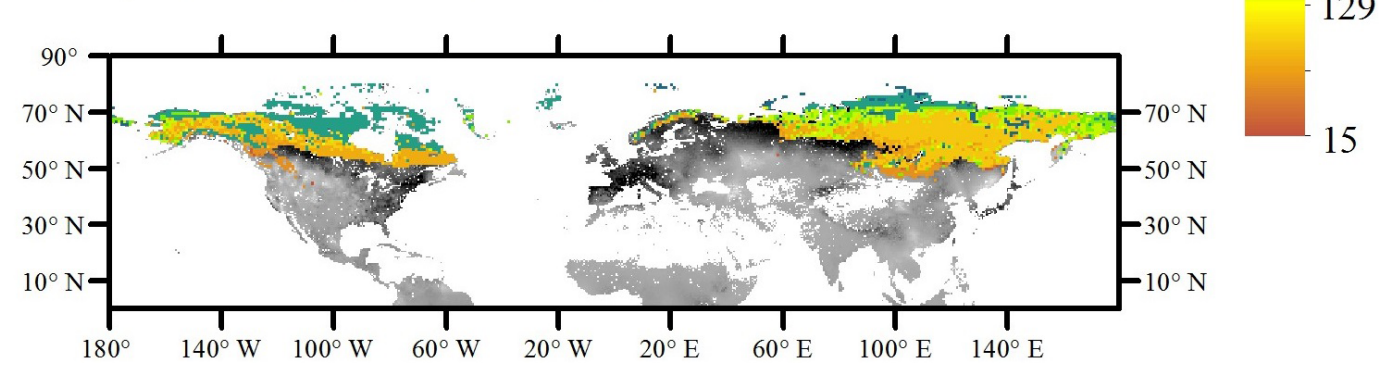

Figure 3. Spatial pattern of mean turnover time (years) at high latitudes based on soil C storage from HWSD data (a) and NCSCD data (b).

their differences. The global average of ecosystem MTT was 25.0 years for GPP-based and 50.8 years for NPP-based estimations, and soil MTT was 35.5 years, which were within the global mean turnover times (26-60 years) estimated by various experimental and modeling approaches (Randerson et al., 1999; Thompson and Randerson, 1999). In our study, the mean GPP-based MTT was slightly longer than that from 23 years, which has been previously reported using the same method (Carvalhais et al., 2014). The difference may have two causes. Firstly, ecosystem $\mathrm{C}$ storage in this study was the sum of soil, vegetation and litter $\mathrm{C}$ pools, whereas Carvalhais et al. (2014) only considered soil and vegetation $C$ pools. Secondly, the data source of global vegetation C storage was different in our study from that of Gibbs (2006), while Carvalhais et al. (2014) used a collection of estimates for pan-tropical regions and radar remote-sensing retrievals for northern and temperate forests. The differences between GPP-based and NPP-based MTT were determined by the ratio of GPP and NPP, which was largely influenced by the assumptions of the MODIS NPP algorithm. The ratio of GPPbased and NPP-based MTT (0.49) was smaller than that estimated by Thompson and Randerson (1999; 0.58, 15 years and 26 years for NPP-based and GPP-based MTT, respectively), largely resulting from different model assumptions for GPP-based (higher normalized storage response function for low turnover time) and NPP-based MTT (for high turnover time) in Thompson and Randerson (1999). Our NPP-based MTTs for the conterminous USA (37.2 years) and Australia (33.4 years) were shorter than the estimates by the inverse models (46 to 78 years; Barrett, 2002; Zhou and Luo, 2008; Zhou et al., 2012). The NPP-based MTT was shorter than the estimated results from Xia et al. (2013) using the CABLE model, although the order of ecosystem MTT across forest biomes was similar. This is because that $C$ turnover time using inverse analysis or CABLE model may be associated with separating ecosystems into several plant and soil $\mathrm{C}$ pools with their distinct $\mathrm{C}$ turnover time, whereas in our study we assumed an ecosystem as one pool.

The spatial patterns of ecosystem and soil MTTs were similar. The magnitude of the difference between NPP-based ecosystem and soil MTTs was determined by the turnover time of vegetation and litter, which was related to plant functional types (PFTs). For instance, the difference between NPP-based and soil MTTs in Australia was smaller (33.4 and 29.8 years, respectively) compared with that in other regions, because one of the PFTs accounting for a large areas of Australia was spare grass with short turnover time ( 3.5 years on average). Additionally, different ecosystems with a specific PFT may have diverse turnover time due to climatic effects. For example, boreal and tropical needleleaf evergreen forest have similar ecosystem $C$ storage ( $\sim 34$ vs. $40 \mathrm{~kg} \mathrm{C} \mathrm{m}^{-2}$ ) and vegetation $\mathrm{C}$ storage $\left(\sim 3.5 \mathrm{~kg} \mathrm{C} \mathrm{m}^{-2}\right)$. However, NPPbased and soil MTTs for boreal needleleaf evergreen forest were about 116 and 98 years, respectively, whereas those for tropical forests were about 12 and 8 years. High temperature and humidity in tropical zones, which promote decomposition processes, may largely contribute to the short turnover time compared to those in boreal zone (Sanderman et al., 2003).

In our study, we only used soil $\mathrm{C}$ in the top $1 \mathrm{~m}$ to estimate ecosystem MTT, which would be underestimated for the large amounts of $\mathrm{C}$ stored between 1 and $3 \mathrm{~m}$ depth (Job- 

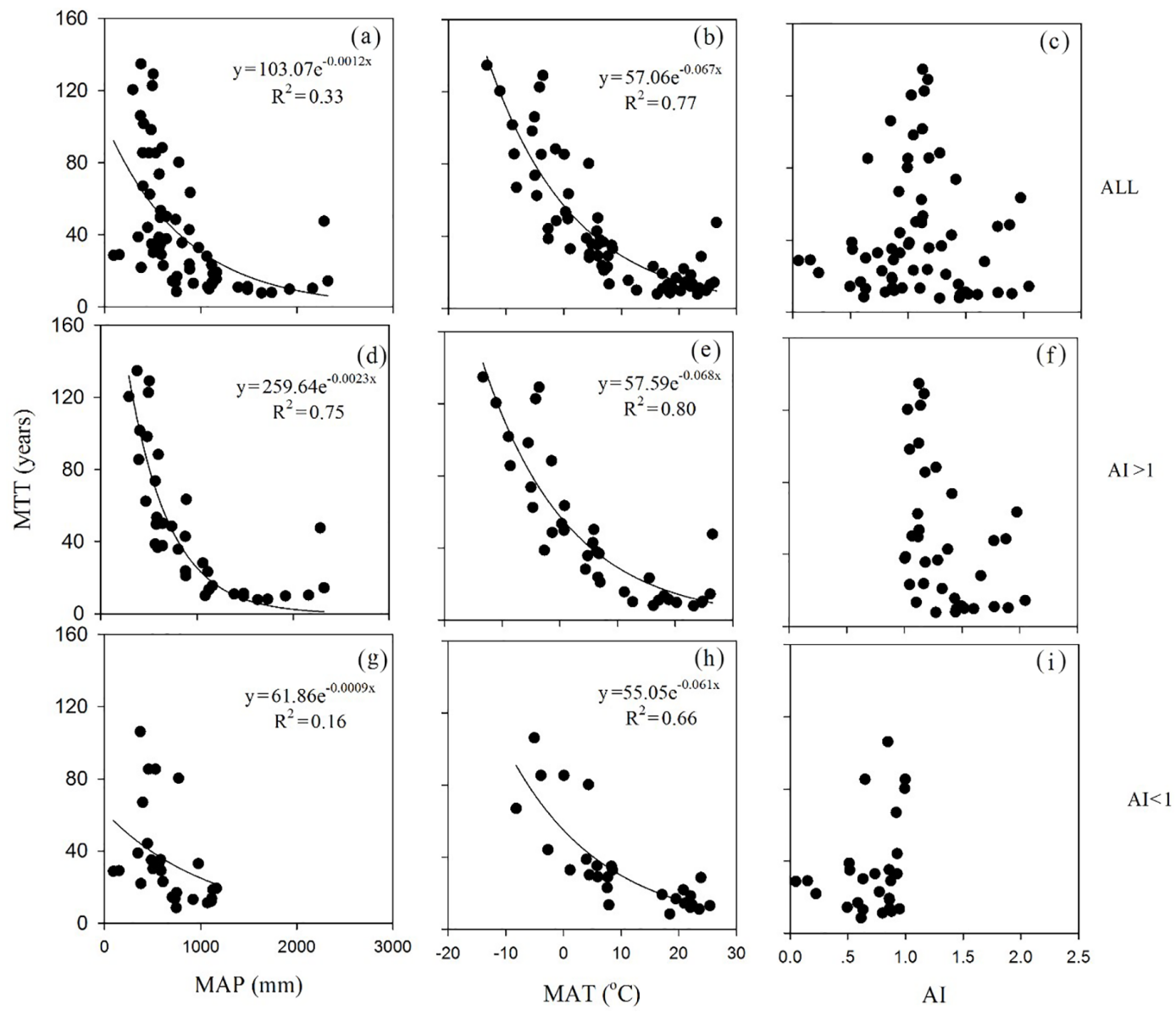

Figure 4. Relationships between ecosystem mean turnover time (MTT) and multi-annual temperature (MAT, b, e, h) or precipitation (MAP, $\mathbf{a}, \mathbf{d}, \mathbf{g}$ ) at different aridity indexes (AI, c, f, i). Each data point stands for average values of each biome. Biomes were assigned into 62 types according to land cover and three temperature zones.

bagy and Jackson, 2000). According to the SOC estimation of Jobbagy and Jackson (2000), the MTT in the top $3 \mathrm{~m}$ could increase to 34.63 years for GPP, 70.68 years for NPP and 55.38 years for soil. Therefore, the $\mathrm{C}$ storage in deep soil layers $(>1 \mathrm{~m})$ should be considered to estimate ecosystem MTT and the accurate estimate of the deep soil $\mathrm{C}$ storage, which deserves to be further explored in the future.

\subsection{The sensitivity of turnover time to climate}

In our study, the estimated MTT was shortest in tropical zones and increased toward high-latitude zones (Fig. 2), which were often affected by the spatial patterns of temperature and moisture. Our results were consistent with previous studies based on SOC (Schimel et al., 1994; Sanderman et al., 2003; Frank et al., 2012; Chen et al., 2013) and root C pools (Gill and Jackson, 2000). Ecosystem MTT had negative exponential relationships with MAT (Fig. 4), similar to those with soil MTT, due to temperature dependence of respiration rates (Lloyd and Taylor, 1994; Wen et al., 2006). Our results showed that the temperature sensitivity of ecosystem MTT was lower than that of soil C pool ( $Q_{10}: 1.95$ vs. 2.23, Figs. 4 and 5), which has also been previously reported (Sanderman et al., 2003), because wood decomposes at much lower rates than soil organic matter (SOM; Zhou et al., 2012). Ecosystem MTT had no significant differences between very humid zone (AI > 1.0) and other zones ( $\mathrm{AI}<1.0$, Fig. 4). However, better relationships between MTT and MAP occurred in very humid zone (AI > 1.0) than other zones, which was similar to soil pool, but soil MTT has higher sensitivity to precipitation than ecosystem MTT under AI > 1. SOM decomposition often increases with added moisture in aerobic soils (Trumbore, 1997; Bai et al., 2017), because the metabolic loss of various $C$ pools increases under warmer and wetter climates (Frank et al., 2012), resulting in high sensitivity of MTT to MAP. Thus, the fitting regression combining MAT and MAP clearly improved soil MTT $\left(R^{2}=0.76, p<0.001\right)$. In arid or semi-humid regions, the increase in $\mathrm{C}$ influx with MAP was more rapid than that in decomposition (Austin and Sala, 2002). In addition, water limitation could suppress the effective ecosystem-level response of respiration to temperature 

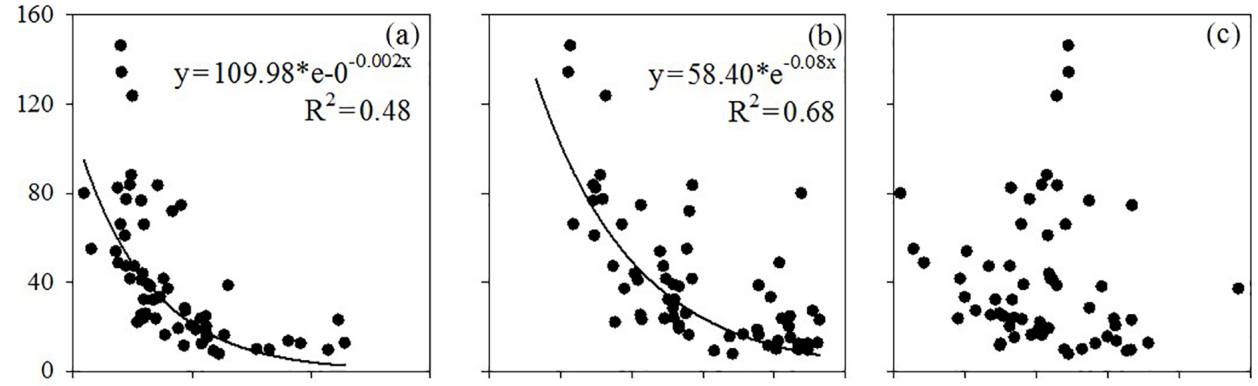

ALL
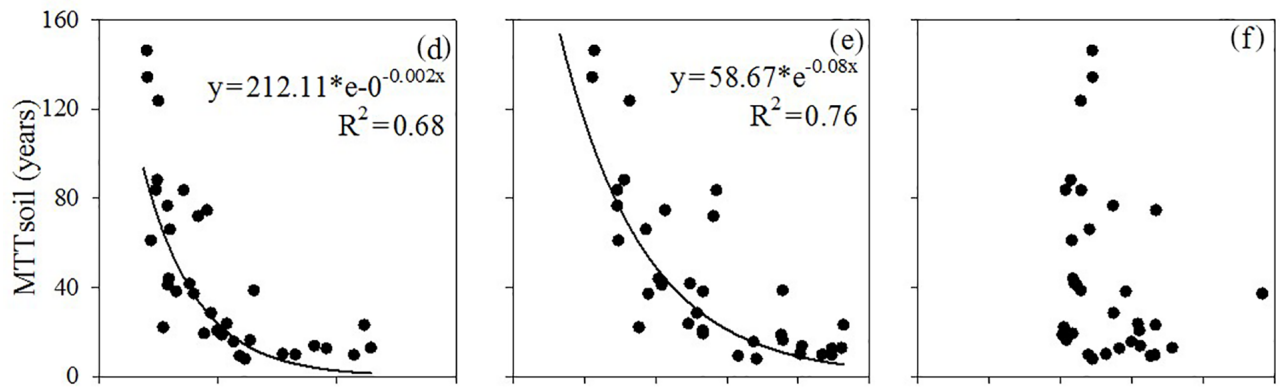

$\mathrm{AI}>1$
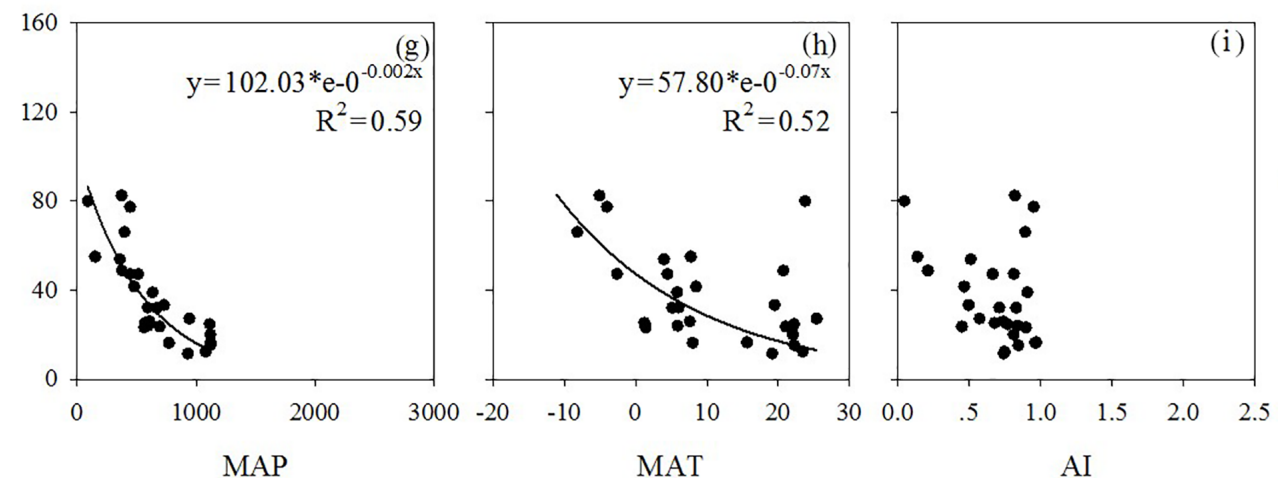

$\mathrm{AI}<1$

Figure 5. Relationships between soil mean turnover time $\left(\mathrm{MTT}_{\text {soil }}\right)$ and multi-annual temperature (MAT, b, e, h) or precipitation (MAP, a, $\mathbf{d}, \mathbf{g})$ at different aridity indexes (AI, c, f, i). Each data point stands for average values of each biome. Biomes were assigned into 62 types according to land cover and three temperature zones.

(Reichstein et al., 2007). On an annual scale, temperature is still the best predictor of MTT (Chen et al., 2013), which explained up to $77 \%$ of variation of MTT (Fig. 4). Other ecosystem properties (e.g., ecosystems types, soil nitrogen) could explain the rest of the variation for the MTT estimation.

\subsection{Effects of the changes in mean turnover time on ecosystem $C$ storage}

Terrestrial ecosystems play an important role in regulating $\mathrm{C}$ balance to combat global change. Current studies suggest that the terrestrial biosphere is currently a net $\mathrm{C}$ sink (Lund et al., 2010), but it is difficult to assess the sustainability of ecosystem C storage due to the complexity of terrestrial ecosystem in response to global change (Luo, 2007; Zhou et al., 2016). In this study, we quantified the changes in ecosystem C storage from 1901 to 2011 and partitioned it into three parts from the changes in NPP, in ecosystem MTT and in both NPP and MTT (see Eq. 3). Our results showed that the decrease in MTT increased ecosystem C loss over time due to the increase in $\mathrm{C}$ decomposition rates. However, increased NPP enhanced ecosystem $\mathrm{C}$ uptake due to the decreased $\mathrm{CO}_{2}$ inputs to atmosphere and increased vegetation $\mathrm{C}$ stocks.

Current data sets have showed an increase in NPP (e.g., Hicke et al., 2002; Potter et al., 2012), leading to increased terrestrial $\mathrm{C}$ uptake. Our results also showed that the NPP increased by approximately $0.3 \mathrm{~kg} \mathrm{C} \mathrm{m}^{-2} \mathrm{yr}^{-1}$ from 1901 to 2011, and the resultant terrestrial $\mathrm{C}$ uptake was $1215.4 \mathrm{Pg} \mathrm{C}$ (with an average year of $11.0 \mathrm{Pg} \mathrm{Cyr}^{-1}$ ). The ecosystem C storage in the conterminous USA increased by $0.4 \mathrm{Pg} \mathrm{C} \mathrm{yr}^{-1}$, which was larger than that from inverse models (Zhou and Luo, 2008; Zhou et al., 2012) and was comparable to C sink from atmospheric inversion $\left(0.30-0.58 \mathrm{Pg} \mathrm{C} \mathrm{yr}^{-1}\right.$; Pacala et al., 2001). The shortened MTT caused C losses from ecosystems from 1901 to 2011 (about $1.45 \mathrm{Pg} \mathrm{C} \mathrm{yr}^{-1}$ ), indicating 
(a) Changes of MTT from 1901 to 2011

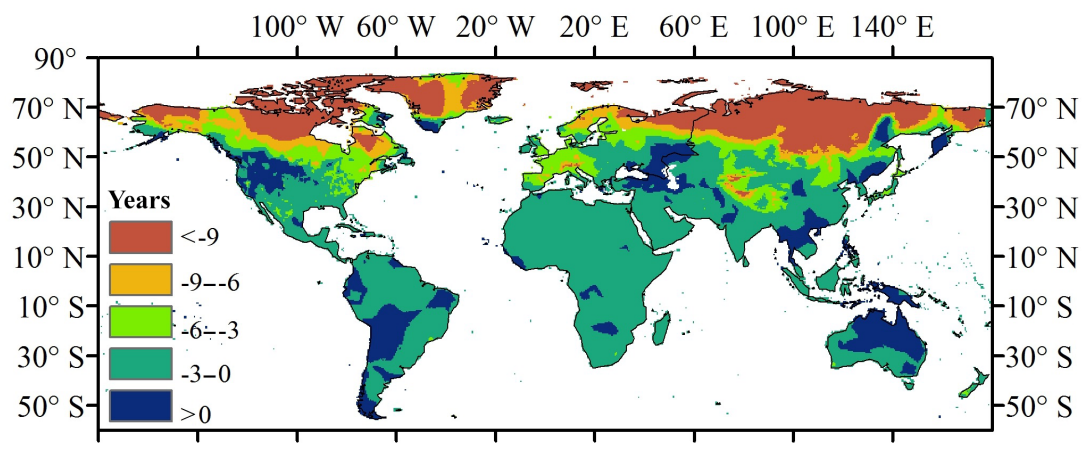

(b) Changes of NPP from 1901 to 2011

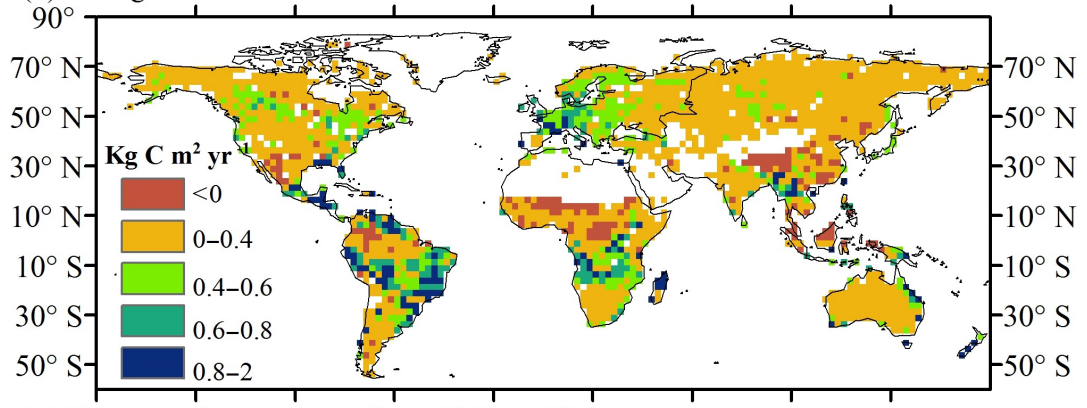

(c) Changes of temperature from 1901 to 2011

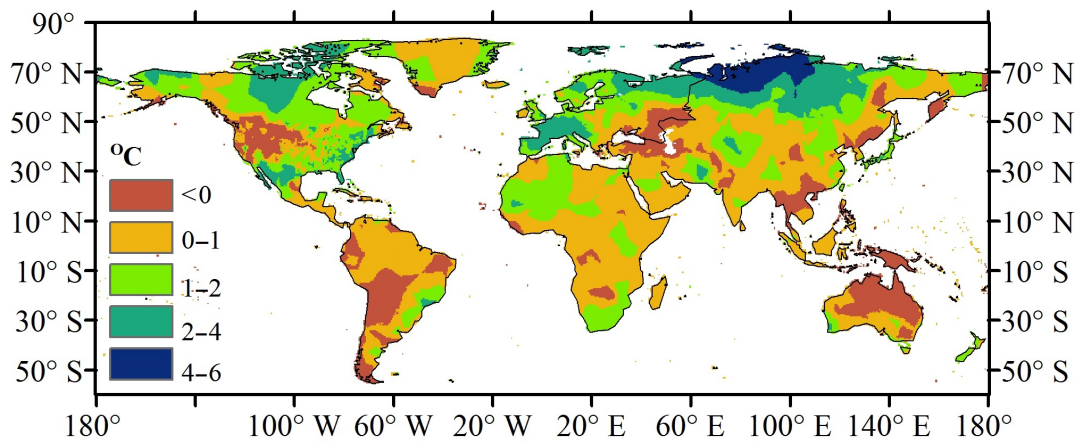

Figure 6. Changes in mean ecosystem mean turnover time (MTT, unit: year) driven by temperature change (a), changes in NPP (unit: $\left.\mathrm{kg} \mathrm{C} \mathrm{m}^{-2} \mathrm{yr}^{-1}, \mathbf{b}\right)$ and changes in temperature $\left({ }^{\circ} \mathrm{C}, \mathbf{c}\right)$ from 1901 to 2011 . Changes in MTT from 1901 and 2011 were calculated by the temperature-dependence function showing in Fig. 4. Changes in NPP from 1901 and 2011 were derived from the models' average and MODIS.

that ecosystem $\mathrm{C}$ storage decreased with climate warming (Fig. 7e). However, ecosystem $\mathrm{C}$ losses from the decrease in MTT only accounted for $13.5 \%$ of that driven by changes in NPP, so terrestrial ecosystem was still a net sink. The largest changes of MTT occurred in high-latitude regions (Fig. 6a), resulting in the largest loss of terrestrial $\mathrm{C}$ (Fig. 7e), where it is more vulnerable to climate change (Zimov et al., 2006). However, the direct release of $\mathrm{CO}_{2}$ at high latitudes through thawing would be another large source of decreasing ecosystem C storage under climate warming (Grosse et al., 2011), which cannot be assessed by MTT or NPP. Interestingly, our results suggested that the substantial changes in terrestrial $\mathrm{C}$ storage occurred in forest and shrubland (50\% of total) due to the relatively longer MTT, leading to the larger terrestrial
C uptake driven by NPP increase compared with others. In addition, the $\mathrm{C}$ uptake in cropland and grassland could be underestimated, probably due to ignoring the effects of land management.

\subsection{Limitation in estimating mean turnover time and its effects to climate}

Estimated MTT in this study was based on C influxes (GPP or NPP) and C pools in plants, litter and soil on the grid scale and can be used to quantify global, regional or biome-specific MTT, which is very important to evaluate terrestrial C storage. However, the balance method and data limitation could cause biases to some degree in estimated ecosystem MTT. 
(a) Altered ecosystem C storage due to changes in MTT

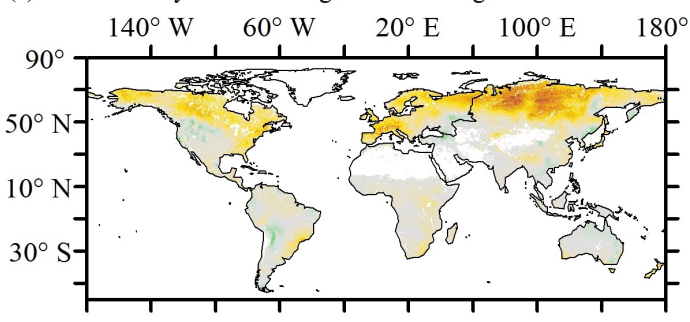

(c) Altered ecosystem $\mathrm{C}$ storage due to changes in MTT $\times$ NPP

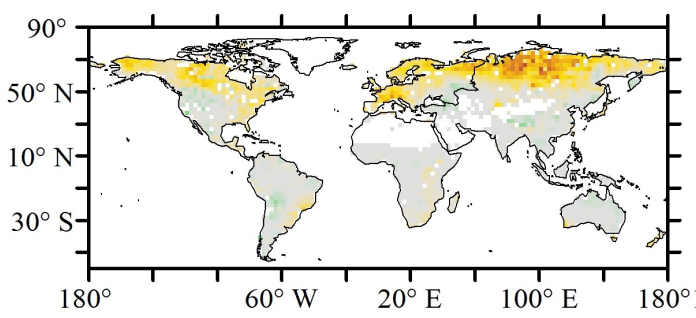

(d) Total altered ecosystem C storage due to both MTT and NPP

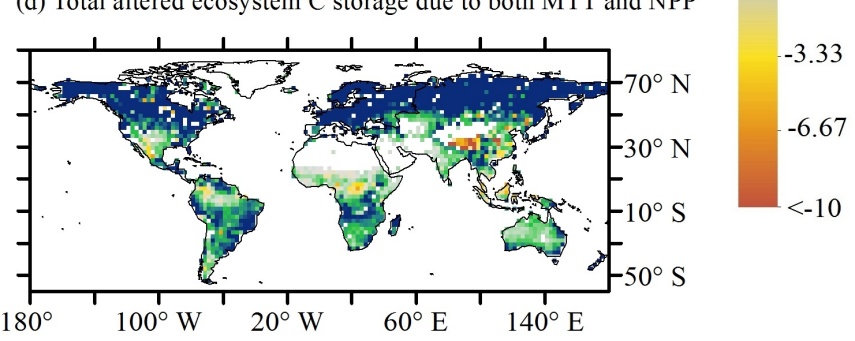

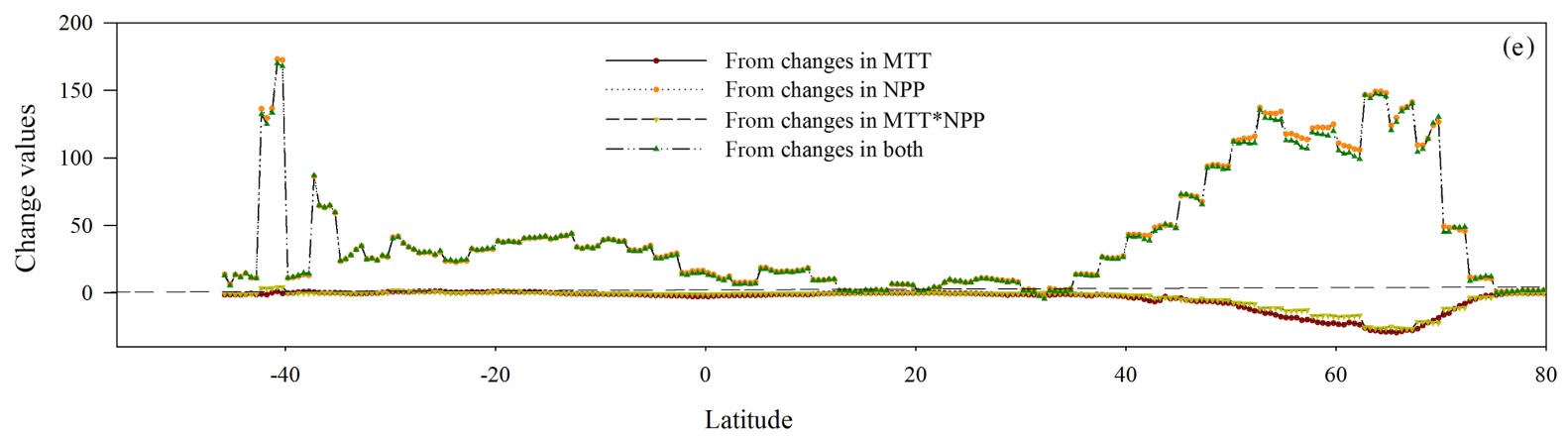

Figure 7. Altered ecosystem carbon storage due to changes in mean turnover time (MTT, NPP2011 $\times \Delta$ MTT, a), net primary production $(\mathrm{NPP}, \mathrm{MTT} 2011 \times \Delta \mathrm{NPP}, \mathbf{b})$ and interaction of NPP and MTT $(\Delta$ MTT $\times \Delta \mathrm{NPP}, \mathbf{c})$. Panels $(\mathbf{d})$ and $(\mathbf{e})$ are total altered ecosystem C storage changes due to changes in MTT, NPP and MTT $\times$ NPP, and their latitudinal gradients from panels (a)-(d), respectively. Unit: $\mathrm{g} \mathrm{C}^{-2} \mathrm{yr}^{-1}$ $\left(\Delta \mathrm{C}_{\text {pool }}=\mathrm{NPP}_{2011} \times \Delta \mathrm{MTT}+\mathrm{MTT}_{2011} \times \Delta \mathrm{NPP}-\Delta \mathrm{NPP} \times \Delta \mathrm{MTT}\right)$.

First, we assumed that ecosystem was at the steady state to estimate MTT. It is difficult to define the steady state, especially for soil C dynamics (Luo and Weng, 2011). In reality, maintaining a steady state is rare for the long term and ecosystems can only approximately reach the steady state in the short term. For example, permafrost is thawing gradually and perhaps catastrophically (Schuur et al., 2008). Second, MTT was estimated on the basis of $\mathrm{C}$ pool and flux measurements. The quality of the current data sets would determine the accuracy of ecosystem MTT estimates. For example, the amendments of typological data (derived from the global ISRIC-WISE data sets) and soil bulk density largely improved the estimates of the SOC storage from HWSD (1417 PgC; Hiederer and Köchy, 2012). Soil C storage calculated from NCSCD data set improves the ecosystem MTT at high latitudes (Fig. 3), compared with that from HWSD data sets. The MTT in the top $1 \mathrm{~m}$ of soil increased to 30.3 years for GPP-based, 66.9 years for NPP-based and 45.7 years for soil when SoilGrids was used compared with HWSD data set
(Hengl et al., 2014). However, it is difficult to quantify the uncertainty in MTT caused by uncertainties of the current data sets due to lack of quantitative uncertainty in these data sets. In addition, disturbance and forest age structure will influence large-scale accumulation biomass, the partitioning of $\mathrm{C}$ into pools with different turnover times and thereby the estimates of long-term $\mathrm{C}$ storage and turnover time (Zaehle et al., 2006), which cannot be reflected in the current algorithms. The inverse modeling is probably a feasible method to evaluate the effect of the disturbance and forest age on the estimates of C turnover time (Zhou et al., 2012).

Third, the uncertainties in the relationships of ecosystem MTT with MAT and MAP would influence the estimates of ecosystem MTT, causing additional uncertainty in ecosystem $\mathrm{C}$ storage. To simplify the calculation, we aggregated all data sets into a biome level, leading to fixed parameters across biomes. However, the response magnitude in soil respiration to warming varied over time and across sites (Rustad et al., 2001; Davidson and Janssens, 2006), re- 
sulting in multiple temperature response functions. Changes in MTT for 1901 and 2011 were estimated using the exponential function between MTT and temperature, resulting in underestimation or overestimation of MTT and the resultant changes on ecosystem $\mathrm{C}$ storage. For example, when the relationship between soil MTT and temperature was used $\left(\mathrm{MTT}_{\text {soil }}=58.40 e^{-0.08 \mathrm{MAT}}\right)$, the soil C storage due to MTT changes (NPP $\times \Delta$ MTT) could decrease by $161.42 \mathrm{Pg} \mathrm{C}$ and that due to NPP changes $(\triangle \mathrm{NPP} \times$ MTT $)$ could increase by 1125.6 Pg C, a similar spatial pattern to the ecosystem. In addition, we assumed that the current-day spatial correlation between temperature and MTT was identical to temporal correlation between these variables. Such assumptions cannot include some processes like acclimation of microbial respiration to warming or shifts in plant species over time.

\subsection{Implication for land surface models}

Our results provided insights as to how MTT and ecosystem C storage varied with climate and over time. Our study could thus offer several suggestions for future experimental and modeling research with the goal of improving estimates of ecosystem C storage. First, the substantial changes in terrestrial $\mathrm{C}$ storage occurred in forest and shrubland covering large areas with relatively long turnover time because MTT dominated the uncertainty in the estimates of terrestrial $\mathrm{C}$ storage. Therefore, further work should focus on the accurate estimation of $\mathrm{C}$ turnover time with numerous observational data on regional or global scales and the evaluation of uncertainty from data sets and the assumption (e.g., the steady state).

Second, there are inconsistent responses of ecosystem C turnover time to climate variables in the current global vegetation models (Friend et al., 2013). Our results showed that the temperature sensitivity of ecosystem $\mathrm{C}$ turnover time was lower than that of soil C pool ( $Q_{10}: 1.95$ vs. 2.23$)$, while the relationship between ecosystem $\mathrm{C}$ turnover time and precipitation under low aridity conditions $(\mathrm{AI}>1)$ was much stronger than those for all other $(\mathrm{AI}<1)$ conditions. Although global C models currently consider moisture stress on vegetation, the incorporation of moisture or precipitation stress into soil decomposition should be strengthened, especially in high-latitude zones with greater warming and increased precipitation.

Data availability. All of the original data (MOD 17, HWSD, NCSCD, vegetation C production of Gibbs et al., 2006, litter data set from Holland et al., 2005, climate variables from the Climate Research Unit, CRU_TS 3.20) used in this study are open and shared. We provided full citations for data sources in the paper and the download links in the Supplement.

The Supplement related to this article is available online at https://doi.org/10.5194/bg-14-5441-2017-supplement.
Competing interests. The authors declare that they have no conflict of interest.

Acknowledgements. This research was financially supported by the National Natural Science Foundation of China (grant no. 31770559, 31370489), 2012 Shanghai Pujiang program (12PJ1401400) and Thousand Young Talents program in China (31370489).

Edited by: Alexey V. Eliseev

Reviewed by: two anonymous referees

\section{References}

Atkin, O. K. and Tjoelker, M. G.: Thermal acclimation and the dynamic response of plant respiration to temperature, Trends Plant Sci., 8, 343-351, 2003.

Austin, A. T. and Sala, O. E.: Carbon and nitrogen dynamics across a natural precipitation gradient in Patagonia, Argentina, J. Veg. Sci., 13, 351-360, 2002.

Bai, S. H., Dempsey, R., Reverchon, F., Blumfield, T. J., Ryan, S., and Cernusak, L.: Effects of forest thinning on soil-plant carbon and nitrogen dynamics, Plant Soil, 411, 437-449, 2017.

Barrett, D. J.: Steady state turnover time of carbon in the Australian terrestrial biosphere, Global Biogeochem. Cy., 16., https://doi.org/10.1029/2002GB001860, 2002.

Bartholomé, E. and Belward, A.: GLC2000: A new approach to global land cover mapping from Earth observation data, Int. J. Remote Sens., 26, 1959-1977, 2005.

Carvalhais, N., Forkel, M., Khomik, M., Bellarby, J., Jung, M., Migliavacca, M., Mu, M. Q., Saatchi, S., Santoro, M., Thurner, M., Weber, U., Ahrens, B., Beer, C., Cescatti, A., Randerson, J. T., and Reichstein, M.: Global covariation of carbon turnover times with climate in terrestrial ecosystems, Nature, 514, 213217, 2014.

Chambers, C. R. S. and Li, T.: Simulation of formation of a nearequatorial typhoon Vamei (2001), Meteorol. Atmos. Phys., 98, 67-80, 2007.

Chen, S., Huang, Y., Zou, J., and Shi, Y.: Mean residence time of global topsoil organic carbon depends on temperature, precipitation and soil nitrogen, Global Planet. Change, 100, 99-108, 2013.

Ciais, P., Friedlingstein, P., Schimel, D. S., and Tans, P. P.: A global calculation of the delta C-13 of soil respired carbon: Implications for the biospheric uptake of anthropogenic $\mathrm{CO}_{2}$, Global Biogeochem. Cy., 13, 519-530, 1999.

Davidson, E. A. and Janssens, I. A.: Temperature sensitivity of soil carbon decomposition and feedbacks to climate change, Nature, 440, 165-173, 2006.

FAO/IIASA/ISRIC/ISSCAS/JRC: Harmonized World Soil Database (version 1.10), FAO, Rome, Italy and IIASA, Laxenburg, Austria, 2012.

Frank, D. A., Pontes, A. W., and McFarlane, K. J.: Controls on soil organic carbon stocks and turnover among North American ecosystems, Ecosystems, 15, 604-615, 2012.

Friend, A. D., Lucht, W., Rademacher, T. T., Keribin, R., Betts, R., Cadule, P., Ciais, P., Clark, D. B., Dankers, R., and Falloon, P. D.: Carbon residence time dominates uncertainty in terrestrial 
vegetation responses to future climate and atmospheric $\mathrm{CO}_{2}, \mathrm{P}$. Natl. Acad. Sci. USA, 201222477, 2013.

Friedlingstein, P., Cox, P., Betts, R., Bopp, L., Von Bloh, W., Brovkin, V., Cadule, P., Doney, S., Eby, M., Fung, I., Bala, G., John, J., Jones, C., Joos, F., Kato, T., Kawamiya, M., Knorr, W., Lindsay, K., Matthews, H.D., Raddatz, T., Rayner, P., Reick, C., Roeckner, E., Schnitzler, K. G., Schnur, R., Strassmann, K., Weaver, A. J., Yoshikawa, C., and Zeng, N.: Climate-carbon cycle feedback analysis: Results from the $\mathrm{C}^{4} \mathrm{MIP}$ model intercomparison, J. Climate, 19, 3337-3353, 2006.

Gibbs, H. K.: Olson's major world ecosytem complexes ranked by carbon in live vegetation: An updated database using the GLC2000 land cover product, NDP-017b, https://doi.org/10.3334/CDIAC/lue.ndp017.2006, 2006.

Gill, R. A. and Jackson, R. B.: Global patterns of root turnover for terrestrial ecosystems, New Phytol., 147, 13-31, 2000.

Grosse, G., Harden, J., Turetsky, M., McGuire, A. D., Camill, P., Tarnocai, C., Frolking, S., Schuur, E. A. G., Jorgenson, T., Marchenko, S., Romanovsky, V., Wickland, K. P., French, N., Waldrop, M., Bourgeau-Chavez, L., and Striegl, R. G.: Vulnerability of high-latitude soil organic carbon in North America to disturbance, J. Geophys. Res.-Biogeo., 116, G00K06, https://doi.org/10.1029/2010JG001507, 2011.

Harris, I., Jones, P. D., Osborn, T. J., and Lister, D. H.: Updated high-resolution grids of montly climate observations, Int. J. Climatol., 34, 623-642, 2014.

Heimann, M. and Reichstein, M.: Terrestrial ecosystem carbon dynamics and climate feedbacks, Nature, 451, 289-292, 2008.

Hengl, T., de Jesus, J. M., MacMillan, R. A., Batjes, N. H., Heuvelink, G. B. M., Ribeiro, E., Samuel-Rosa, A., Kempen, B., Leenaars, J. G. B., Walsh, M. G., and Gonzalez, M. R.: SoilGrids1km - Global Soil Information Based on Automated Mapping, Plos One, 9, e105992, https://doi.org/10.1371/journal.pone.0105992, 2014.

Hicke, J. A., Asner, G. P., Randerson, J. T., Tucker, C., Los, S., Birdsey, R., Jenkins, J. C., and Field, C.: Trends in North American net primary productivity derived from satellite observations, 1982-1998, Global Biogeochem. Сy., 16, 1018, https://doi.org/10.1029/2001GB001550, 2002.

Hiederer, R. and Köchy, M.: Global soil organic carbon estimates and the Harmonized World Soil Database, EUR Scientific and Technical Research series, ISSN 1831-9424 (online), ISSN 1018-5593 (print), ISBN 1978-1892-1879-23108-23107, https://doi.org/23110.22788/13267, 2012.

Holland, E. A., Post, W. M., Matthews, E. G., Sulzman, J. M., Staufer, R., and Krankina, O. N.: A Global Database of Litterfall Mass and Litter Pool Carbon and Nutrients, ORNL DAAC, Oak Ridge, Tennessee, USA, https://doi.org/10.3334/ORNLDAAC/1244, 2014

IPCC: Climate change 2007: The physical science basis, edited by: Solomon, S., Manning, D. Q. M., Chen, Z., Marquis, M., Averyt, K. B., Tignor, M., and Miller, H. L., Cambridge, UK and New York, NY, USA, 2007.

Jobbagy, E. G. and Jackson, R. B.: The vertical distribution of soil organic carbon and its relation to climate and vegetation, Ecol. Appl., 10, 423-436, 2000.

Karhu, K., Auffret, M. D., Dungait, J. A. J., Hopkins, D. W., Prosser, J. I., Singh, B. K., Subke, J.-A., Wookey, P. A., Agren, G. I., Sebastia, M.-T., Gouriveau, F., Bergkvist, G., Meir, P., Notting- ham, A. T., Salinas, N., and Hartley, I. P.: Temperature sensitivity of soil respiration rates enhanced by microbial community response, Nature, 513, 81-84, 2014.

Lloyd, J. and Taylor, J.: On the temperature dependence of soil respiration, Funct. Ecol., 8, 315-323, 1994.

Lund, M., Lafleur, P. M., Roulet, N.T., Lindroth, A., Christensen, T. R., Aurela, M., Chojnicki, B. H., Flanagan, L. B., Humphreys, E. R., and Laurila, T.: Variability in exchange of $\mathrm{CO}_{2}$ across 12 northern peatland and tundra sites, Glob. Change Biol., 16, 24362448, 2010.

Luo, Y. and Weng, E.: Dynamic disequilibrium of the terrestrial carbon cycle under global change, Trends Ecol. Evol., 26, 96-104, 2011.

Luo, Y., Hui, D., and Zhang, D.: Elevated $\mathrm{CO}_{2}$ stimulates net accumulations of carbon and nitrogen in land ecosystems: A metaanalysis, Ecology 87, 53-63, 2006.

Luo, Y.: Terrestrial carbon-cycle feedback to climate warming, Annu. Rev. Ecol. Evol. Syst., 38, 683-712, 2007.

Luo, Y. Q., White, L. W., Canadell, J. G., DeLucia, E. H., Ellsworth, D. S., Finzi, A. C., Lichter, J., and Schlesinger, W. H.: Sustainability of terrestrial carbon sequestration: A case study in Duke Forest with inversion approach, Global Biogeochem. Cy., 17, https://doi.org/10.1029/2002GB001923, 2003.

Martin, A. D., Kevin, M. Q., and Jong, H. P.: MCMCpack: Markov chain monte carlo in R, J. Stat. Softw., 42, https://doi.org/10.18637/jss.v042.i09, 2011.

Matthews, E.: Global litter production, pools, and turnover times: Estimates from measurement data and regression models, J. Geophys. Res., 102, 18771, https://doi.org/10.1029/97JD02956, 1997.

Middleton, N. and Thomas, D.: World atlas of desertification Arnold, Hodder Headline, PLC, 1997.

Nemani, R. R., Keeling, C. D., Hashimoto, H., Jolly, W. M., Piper, S. C., Tucker, C. J., Myneni, R. B., and Running, S. W.: Climatedriven increases in global terrestrial net primary production from 1982 to 1999, Science, 300, 1560-1563, 2003.

Norby, R. J., DeLucia, E. H., Gielen, B., Calfapietra, C., Giardina, C. P., King, J. S., Ledford, J., McCarthy, H. R., Moore, D. J. P., Ceulemans, R., De Angelis, P., Finzi, A. C., Karnosky, D. F., Kubiske, M. E., Lukac, M., Pregitzer, K. S., Scarascia-Mugnozza, G. E., Schlesinger, W. H., and Oren, R. : Forest response to elevated $\mathrm{CO}_{2}$ is conserved across a broad range of productivity, $\mathrm{P}$. Natl. Acad. Sci. USA, 102, 18052-18056, 2005.

Olson, J. S., Watts, J. A., and Allison, L. J.: Carbon in live vegetation of major world ecosystems, Oak Ridge National Lab., TN (USA), 1983.

Olson, J. S., Watts, J. A., and Allison, L. J.: Major world ecosystem complexes ranked by carbon in live vegetation: A database, NDP-017, Oak Ridge Lab., Oak Ridge, Tenn., 1985.

Pacala, S. W., Hurtt, G. C., Baker, D., Peylin, P., and Houghton, R. A.: Consistent Land- and Atmosphere-Based U.S. Carbon Sink Estimates, Science, 292, 2316-2320, 2001.

Parton, W. J., Schimel, D. S., Cole, C. V., and Ojima, D. S.: Analysis of factors controlling soil organic matter levels in Great Plains grasslands, Soil Sci. Soc. Am. J., 51, 1173-1179, 1987.

Potter, C. S., Randerson, J. T., Field, C. B., Matson, P. A., Vitousek, P. M., Mooney, H. A., and Klooster, S. A.: Terrestrial ecosystem production - a process model-based on global satellite and surface data, Global Biogeochem. Cy., 7, 811-841, 1993. 
Potter, C., Klooster, S., and Genovese, V.: Net primary production of terrestrial ecosystems from 2000 to 2009, Climatic Change, 115, 365-378, 2012.

Randerson, J. T., Thompson, M. V., and Field, C. B.: Linking C13-based estimates of land and ocean sinks with predictions of carbon storage from $\mathrm{CO}_{2}$ fertilization of plant growth, Tellus B, 51, 668-678, 1999.

Reichstein, M., Papale, D., Valentini, R., Aubinet, M., Bernhofer, C., Knohl, A., Laurila, T., Lindroth, A., Moors, E., Pilegaard, K., and Seufert, G.: Determinants of terrestrial ecosystem carbon balance inferred from European eddy covariance flux sites, Geophys. Res. Lett., 34, https://doi.org/10.1029/2006GL027880, 2007.

Rustad, L., Campbell, J., Marion, G., Norby, R., Mitchell, M., Hartley, A., Cornelissen, J., and Gurevitch, J.: A meta-analysis of the response of soil respiration, net nitrogen mineralization, and aboveground plant growth to experimental ecosystem warming, Oecologia, 126, 543-562, 2001.

Sanderman, J., Amundson, R. G., and Baldocchi, D. D.: Application of eddy covariance measurements to the temperature dependence of soil organic matter mean residence time, Global Biogeochem. Cy., 17, https://doi.org/10.1029/2001GB001833, 2003.

Schimel, D. S., Braswell, B. H., Holland, E. A., Mckeown, R., Ojima, D. S., Painter, T. H., Parton, W. J., and Townsend, A. R.: Climatic, edaphic, and biotic controls over storage and turnover of carbon in soils, Global Biogeochem. Cy., 8, 279-293, 1994.

Schuur, E. A. G., Bockheim, J., Canadell, J. G., Euskirchen, E., Field, C. B., Goryachkin, S. V., Hagemann, S., Kuhry, P., Lafleur, P. M., Lee, H., Mazhitova, G., Nelson, F. E., Rinke, A., Romanovsky, V. E., Shiklomanov, N., Tarnocai, C., Venevsky, S., Vogel, J. G., and Zimov, S. A.: Vulnerability of permafrost carbon to climate change: Implications for the global carbon cycle, Bioscience, 58, 701-714, 2008.

StatSoft, Inc.: Electronic Statistics Textbook. Tulsa, OK: StatSoft, available at: http://www.statsoft.com/textbook/ (last access: 1 December 2017), 2011.

Strassmann, K. M., Joos, F., and Fischer, G.: Simulating effects of land use changes on carbon fluxes: Past contributions to atmospheric $\mathrm{CO}_{2}$ increases and future commitments due to losses of terrestrial sink capacity, Tellus B, 60, 583-603, 2008.

Tarnocai, C., Canadell, J. G., Schuur, E. A. G., Kuhry, P., Mazhitova, G., and Zimov, S.: Soil organic carbon pools in the northern circumpolar permafrost region, Global Biogeochem. Cy., 23, https://doi.org/10.1029/2008GB003327, 2009.

Thompson, M. V. and Randerson, J. T.: Impulse response functions of terrestrial carbon cycle models: method and application, Glob. Change Biol., 5, 371-394, 1999.

Todd-Brown, K. E. O., Randerson, J. T., Post, W. M., Hoffman, F. M., Tarnocai, C., Schuur, E. A. G., and Allison, S. D.: Causes of variation in soil carbon simulations from CMIP5 Earth system models and comparison with observations, Biogeosciences, 10, 1717-1736, https://doi.org/10.5194/bg-10-1717-2013, 2013.
Trumbore, S. E.: Potential responses of soil organic carbon to global environmental change, P. Natl. Acad. Sci. USA, 94, 8284-8291, 1997.

Trumbore, S. E., Torn, M. S., and Chadwick, O. A.: Recent ams measurements of $\mathrm{C}-14$ in soil organic matter: Understanding controls of carbon storage and turnover in soils, Abstracts of Papers of the American Chemical Society, 211, 17-Geoc., 1996.

Vogt, K. A., Vogt, D. J., Palmiotto, P. A., Boon, P., O'Hara, J., and Asbjornsen, H.: Review of root dynamics in forest ecosystems grouped by climate, climatic forest type and species, Plant Soil, 187, 159-219, 1995.

Wen, X. F., Yu, G. R., Sun, X.M., Li, Q. K., Liu, Y. F., Zhang, L. M., Ren, C. Y., Fu, Y. L., and Li, Z. Q.: Soil moisture effect on the temperature dependence of ecosystem respiration in a subtropical Pinus plantation of southeastern China, Agr. Forest Meteorol., 137, 166-175, 2006.

Xia, J., Luo, Y., Wang, Y. P., and Hararuk, O.: Traceable components of terrestrial carbon storage capacity in biogeochemical models, Glob. Change Biol., 19, 2104-2116, 2013.

Yan, Y., Luo, Y., Zhou, X., and Chen, J.: Sources of variation in simulated ecosystem carbon storage capacity from the 5th Climate Model Intercomparison Project (CMIP5), Tellus B, 66, 22568, https://doi.org/10.3402/tellusb.v66.22568, 2014.

Zaehle, S., Sitch, S., Prentice, I. C., Liski, J., Cramer, W., Erhard, M., Hickler, T., and Smith B.: The importance of age-related decline in forest NPP for modeling regional carbon balances, Ecol. Appl., 16, 1555-1574, 2006.

Zhao, M. and Running, S. W.: Drought-induced reduction in global terrestrial net primary production from 2000 through 2009, Science, 329, 940-943, 2010.

Zhou, L., Zhou, X., Shao, J., Nie, Y., He, Y., Wu, Z., and Bai, S. H.: Interactive effects of global change factors on soil respiration and its components: a meta-analysis, Glob. Change Biol., 22, 31573169, 2016.

Zhou, T. and Luo, Y. Q.: Spatial patterns of ecosystem carbon residence time and NPP-driven carbon uptake in the conterminous United States, Global Biogeochem. Cy., 22, https://doi.org/10.1029/2007GB002939, 2008.

Zhou, X., Zhou, T., and Luo, Y.: Uncertainties in carbon residence time and NPP-driven carbon uptake in terrestrial ecoystems of the conterminous USA: A Bayesian approach, Tellus B, 64, 17223, https://doi.org/10.3402/tellusb.v64i0.17223, 2012.

Zimov, S., Davydov, S., Zimova, G., Davydova, A., Schuur, E., Dutta, K., and Chapin III, F.: Permafrost carbon: Stock and decomposability of a globally significant carbon pool, Geophys. Res. Lett., 33, L20502, https://doi.org/10.1029/2006GL027484, 2006. 